\title{
Fritidshem - ett gränsland i utbildningslandskapet
}

\section{Lärare i fritidshems institutionella identitet}

\author{
Ann Ludvigsson* og Carin Falkner \\ fönköping University, fönköping, Sverige
}

\begin{abstract}
Sammanfattning
Fritidshemmet utgör en väsentlig del av grundskolan och är positionerat som ett gränsland i det svenska utbildningslandskapet, mellan förskola, förskoleklass och grundskola. Mot bakgrund av fritidshemmets positionering som gränsland och de stora strukturella förändringar som genomförts under senare årtionden är syftet med artikeln att diskutera hur lärare i fritidshem konstruerar en gemensam förståelse av sitt uppdrag - en institutionell identitet - utifrån fritidshemmets position i utbildningslandskapet. Artikeln bygger på en studie med två fokusgruppssamtal med sammanlagt åtta lärare. För att tolka resultatet används begreppen gränsland, kultur och institutionell identitet. Lärarnas institutionella identitet beskrivs i fokusgruppssamtalen med ord som uttrycker att de är: "lagspelare", "föränderliga", "flexibla", "fyrkantiga", "professionella" och "logistiker". Centralt för lärarna är att skapa trygghet och de säger sig göra det genom: att vara tydliga i ledarskapet, relationsskapa med elever och föräldrar, kontrollera vad eleverna gör och befinner sig samt organisera elevgruppen och verksamheten. Lärarna upplever att deras uppdrag är otydligt och att rektorer brister i sin kunskap om fritidshem och därmed i sitt ledarskap. Dessa omständigheter kompenseras av lärarna genom att de anstränger sig för att visa sig professionella.
\end{abstract}

\section{Nyckelord: Lärare; undervisning; trygghet; rektor; pedagogiskt ledarskap}

Mottagit: Februar, 2018; Godkänt: Februar, 2019; Publicerat: April, 2019

\section{Abstract \\ Leisure-Time Centres - A Borderland in the Educational Landscape: The Institutional Identity of Teachers in Leisure-Time Centres}

The leisure-time centre is an essential part of the Swedish education system. It is positioned as a borderland in the educational landscape, between preschool, preschool class and compulsory school. Conflicting expectations and different conditions influence the fulfilment of teacher in leisure-time centres tasks. Against the background of the position of leisure-time centres within the education system and the major structural changes carried out during recent decades, this article describes how teachers in leisure-time centres perceive their mission and the importance of the structural conditions surrounding the leisure-time centre. This article analyses how the teachers construct their identities within the institution. The empirical data consists of two focus group

\footnotetext{
^Korrespondanse: Ann Ludvigsson, Högskolan för lärande och kommunikation, Box 1026, 55111 Jönköping, Sverige. E-mail: ann.ludvigsson@ju.se 
interviews. The teachers describe their identities in such terms as 'team player', 'flexible but inflexible in some situations', and 'professional and logistical'. Central to the teachers' mission is creating the conditions for security, which they achieve through being clear in their leadership, through their approach to students and parents and through organizing activities to manage the students and maintain order. The teachers consider their educational mission to be unclear. They also cite a general problem of principals who lack sufficient knowledge about the leisure-time centre, which results in a lack of leadership.

Keywords: Teacher; teaching; confidence; principal; educational leadership

\section{Ett gränsland i förändring}

Fritidshem är en relativt ung verksamhet, men med rötter i 1800-talets arbetsstugor. Yrket grundlärare $i$ fritidshem, vilket tidigare hette fritidspedagog, är ett yrke något yngre än fritidshemsverksamheten (Författarreferens). Drygt 478000 elever är inskrivna i fritidshem och det innebär att det är ungefär 130000 fler som går i fritidshem än i gymnasieskolan. I de lägre skolåldrarna (6-9 år) utgör andelen inskrivna elever nästan 84 procent (Skolverket, 2017). Fritidshem är en frivillig verksamhet och utgör en väsentlig del av grundskolans verksamhet, men också av elevers vardag. Sedan många år följer fritidshemmet läroplanen i tillämpliga delar och sedan 2016 finns ett eget kapitel i läroplanen som förtydligar fritidshemmets syfte och innehåll (Skolverket, 2016). Där framgår att "fritidshemmet ska stimulera elevernas utveckling och lärande samt erbjuda eleverna en meningsfull fritid" (s. 24). Utgångspunkten för undervisningen ska tas i elevernas behov, nyfikenhet, intressen, erfarenheter och initiativ. Arbetet är grupporienterat och "syftar till att främja elevernas fantasi och förmåga att lära tillsammans med andra genom lek, rörelse och skapande genom estetiska uttrycksformer samt med utforskande och praktiska arbetssätt”" (s. 24).

I samband med decentraliseringen och införandet av mål- och resultatstyrning under 1990-talet fick förskoleklassen, fritidshemmet och skolan Utbildningsdepartementet som gemensam huvudman. Integreringen av verksamheterna ansågs viktig för att skapa en helhet i den pedagogiska verksamheten för barns utveckling och lärande. Arbetslaget med olika lärarkompetenser angavs som förutsättning för det arbetet (SOU:1997:21). Sedan decentraliseringen har utbygganden av fritidshemmen skett mycket snabbt, framförallt för barn i de yngre skolåldrarna. Utbyggnaden har skett parallellt med stora nedskärningar vilket fått till följd att elevgrupperna blivit större, personaltätheten lägre och lokalerna ofta både mindre och sämre anpassade för fritidshemsverksamhet (Skolverket, 2000; 2005; Skolinspektionen 2010; 2018). Samtidigt saknar i dagsläget 58 procent av de anställda en pedagogisk högskoleexamen (Skolverket, 2017). De senaste årtiondenas förändringar har inneburit att förutsättningarna för lärare i fritidshem att uppfylla sitt uppdrag präglas av osäkerhet och ojämlika villkor. Decentraliseringen innebar också att rektor blev ledare för fritidshem. Skolinspektionen konstaterar en bristande kännedom hos många rektorer om gällande styrdokument för fritidshem och att skolledningen endast i liten 
utsträckning engagerar sig i utvecklingen av fritidshemmets verksamhet (Skolinspektionen, 2010; 2018).

I Sverige tycks det vara en ambition från politiskt håll att utvidga skoldagen för barn i skolåldern (SFS 2010:800; Skolverket, 2016). Elevers tid i fritidshem ska innehålla aktiviteter som stödjer skolarbetet och kompletterar grundskolans undervisning. Samtidigt har det blivit en ökad fokusering på kunskapseffektivitet i grundskolan. Elevers tid i fritidshem tycks bli alltmer institutionaliserad i takt med den kunskapseffektiva skolans utbredning (Andersson, 2010; Saar, Löfdahl \& Hjalmarsson, 2012). Fenomenet kan iakttas även i Norge och Danmark (Öksnes, Knutas, Ludvigsson, Falkner \& Kjaer, 2014) liksom i länder utanför Norden och Europa, vilket lett till ett ökat fokus på tiden utanför den obligatoriska undervisningen. Fritiden organiseras genom schemalagda aktiviteter med målet att aktiviteterna ska gynna både lärandet i allmänhet och skolprestationerna (Stecher et al., 2013). Hjalmarsson (2013) visar hur lärare i fritidshem hanterar dilemmat att verksamheten ska vara meningsfull och bidra till måluppfyllelsen samtidigt som den ska vara frivillig och utgå från elevernas intressen. Genom att erbjuda aktiviteter som lärarna tror sig veta att eleverna är intresserade av styr de in eleverna i dessa. Gränslandets problematik och de olika skolformernas positioner i utbildningslandskapet blir här synliga i de ökade krav som ställs på fritidshemmet att förbereda elever för skolarbetet, samtidigt som det ska vara en plats för lek och meningsfull fritid (Skolverket, 2014; Skolverket, 2016).

Flera forskare har fokuserat på kulturella förhållanden och skillnader mellan de båda verksamheterna (Calander, 1999; Haglund, 2004; Hansen, 1999; Johansson, 2000). Ludvigsson (2009) visar på kulturella skillnader mellan lärare i förskola, fritidshem och obligatorisk grundskola kring synen på det pedagogiska arbetet, förhållningssätt till elevernas lärande och organisering av arbetet. Närvänen och Elvstrand (2014) menar att yrkesrollen för lärare i fritidshem har blivit otydlig i förhållande till lärares i den obligatoriska undervisningen. De konstaterar att det finns en maktobalans mellan lärarkategorierna. Lärarna i den obligatoriska undervisningen har tolkningsföreträde även när det gäller vad lärarna i fritidshem ska göra i den obligatoriska undervisningen.

Mot bakgrund av fritidshemmets position i utbildningslandskapet och de stora strukturella förändringar som genomförts är syftet med artikeln att utifrån en genomförd studie analysera hur lärare i fritidshem ger uttryck för en gemensam förståelse av sitt uppdrag - en institutionell identitet - utifrån fritidshemmets position i utbildningslandskapet. Med institutionell identitet avses den identitet som utvecklas bland medlemmar i en organisation (eller del av organisation), i det här fallet bland lärare i fritidshem, såsom att medlemmarna delar föreställningar om vad de yttre gränserna för den grupp man tillhör går (Alvesson, 2007). Institutionell identitet innebär vidare en gemensam förståelse av uppdraget i förhållande till föreställningar, värderingar och intressen som lärare ger uttryck för. Den institutionella identiteten har betydelse 
för hur lärarna manövrerar i det gränsland där fritidshemmet är positionerat. Frågor som besvaras i artikeln är:

- Hur uttrycker lärarna sin institutionella identitet? Frågan fokuserar på hur lärarna beskriver vem de är och vad de gör som lärargrupp.

- Hur beskriver lärarna innebörden av att befinna sig i gränslandet fritidshem? Frågan fokuserar på konsekvenser av processer som gränsdragningar mellan lärargrupper får.

- Vilken betydelse uttrycker lärarna att rektors ledarskap har för fritidshemmet och för dem som lärargrupp?

\section{Teoretiska utgångspunkter}

Nyinstitutionell teori utgör studiens huvudsakliga perspektiv. Med teorin kan institutionaliserade handlingar uppmärksammas och blicken riktas mot inflytandet av kulturbestämda regler som föreställningar, värderingar och intressen samt vilka innebörder dessa kan ha för agerandet i olika verksamheter (Brunsson \& Olsen, 1990; Johansson, 2002; Johansson, 2009; Meyer \& Rowan, 1977; Powell \& Colyvas, 2008). Fritidshem och obligatorisk grundskola har olika traditioner och positioner i utbildningslandskapet. För att fördjupa analysen av hur lärare i fritidshem konstruerar förståelse för sitt uppdrag utifrån fritidshemmets position används begreppet institutionell identitet. Gränsland uppstår genom att gränser dras mellan olika verksamheter. Gränsdragningar är processer där gränsdragningen i sig blir avgörande för vem eller vilka som kommer inkluderas eller exkluderas. "Borders constitute institutions that enable legitimation, signification and domination, creating a system of order through which control can be exercised" (Newman, 2006, s. 148). För att förstå lärare i fritidshems omgivning och hur de formar en institutionell identitet utifrån fritidshemmets position är kulturbegreppet centralt. Kultur förstås "som föreställningar och innebörder som är gemensamma för en viss grupp, som ofta uttrycks eller förmedlas i symbolisk form och som vägleder människor i hur de relaterar till sin gemensamma omvärld" (Alvesson, 2007, s. 204). De olika gränsländerna kan beskrivas som sociala världar där lärare inom ett och samma gränsland har sitt sätt att uppfatta skolan, eleverna och undervisningen (Siskin, 1994). Enligt Shibutani (1955) fungerar föreställningar, värderingar och normer som referensramar för individer inom grupper, vilka de förhåller sig till och agerar utifrån. Lärare inom samma verksamhet är lojala mot varandra och tillsammans skapar de olika rutiner, värderingar och normer i arbetet. De förklarar vilka de är, vad de gör och hur de gör genom att förankra sin identitet, sina handlingar och sin förståelse i verksamheten (Ackesjö \& Persson, 2010; Siskin, 1994). Grupper kan också förstås som mikropolitiska arenor och handlingar blir politiska när de agerar utifrån sina intressen och överenskommelser. Det en grupp ser som fördel kan en annan se som en nackdel (Hosking \& Fineman, 1990; Siskin, 1994). Ackesjö och Landefrö (2014) skriver att "konstruktioner 
av identiteter och gränser är i sig självt sammanflätade, och i denna process ingår även att förhålla sig till platsen och till de Andra” (s. 32).

\section{Metod}

Artikeln bygger på en studie bestående av två fokusgruppssamtal med fyra yrkesverksamma lärare i fritidshem i varje samtal. Fokusgruppssamtal ger rik information och har möjlighet att bli självverkande i bemärkelsen att tankar som uttrycks av någon fångas upp och utvecklas av andra. Fyra deltagare finner Morgan (1997) lämpligt i en grupp där samtalsämnet är väl känt för deltagarna. Urvalet har genomförts i tre steg. Det första steget härrör från en tidigare datainsamling där ett större antal lärare i fritidshem tillfrågats om intresse att besvara en enkät med öppna intervjufrågor om sin profession och sitt uppdrag. 22 lärare valde att besvara enkäten. Av dessa tillfrågades åtta stycken om att delta i ett fokusgruppssamtal. Samtliga tackade ja. Dessa valdes för att de är utbildade fritidspedagoger/lärare i fritidshem ${ }^{1}$ med flera års erfarenhet av arbete i fritidshem. Lärarna arbetar i två olika kommuner, på sex olika skolor och alla utom två arbetar på olika fritidshem. Valet av lärare från olika fritidshem gjordes för att få en spridning och minska risken för grupptänkande (Morgan, 1997). Meningen med fokusgruppssamtalen var att föra ett fördjupat samtal med lärarna om deras yrkesidentitet med utgångspunkt i begrepp som sammanfattar återkommande teman i enkätresultatet (delaktighet, medbestämmande, jämlikhet, tillhörighet, kompensation). Ur enkätresultatet har även citat kring rektors ledarskap använts som stimulimaterial i samtalen: "fritidshemsverksamheten kommer alltid i andra hand", ledning som är "engagerad, intresserad och lyhörd", ledning som "saknar kunskaper" om fritidshemsverksamheten. Begreppen och citraten lades ut i form av lappar på bordet kring vilket respondenterna satt. Först behandlades begreppen och därefter citaten. Vid samtalen har en forskare agerat moderator och den andra observerande bisittare. Samtalen genomfördes på två fritidshem och spelades in digitalt (utan bild). Samtalen har transkriberats i sin helhet av författarna.

Fokusgruppssamtalen har analyserats på det sätt som Kvale (1997) benämner meningskategorisering och meningstolkning. Meningskategorisering innebär att innehållet i intervjuerna grupperas i kategorier med likartat innehåll. Kategori är här ett väl stort ord, innehållet i intervjuerna har snarare grupperats med hjälp av uttryck ur fokusgruppssamtalen som täcker in olika resonemang som lärarna för kring vilka de är: lagspelare, föränderliga, flexibla, fyrkantiga, professionella och logistiker och vad de gör: tydliga i att leda, relationsskapa, kontrollerar vad elever gör och befinner sig, organiserar elevgruppen samt fritidsverksamheten i sig. Det förstnämnda innehållet redovisas under rubriken Vad lärare i fritidshem är och det sistnämnda under rubriken

\footnotetext{
${ }^{1}$ Sedan 2010 benämns lärarutbildade som arbetar i fritidshem som grundlärare med inriktning mot arbete i fritidshem. I artikeln används företrädesvis lärare i fritidshem, men andra yrkesbeteckningar förekommer också beroende på vilka yrkesgrupper som refererade studier undersökt.
} 


\section{Ann Ludvigsson og Carin Falkner}

Vad lärare i fritidshem gör och inte gör. Uttryck som lärarna använder för att beskriva rektors ledarskap är: samspel, förhållningssätt och statusskillnader. Innehållet redovisas under rubriken Ledarskap i gränslandet fritidshem. Vid citering i resultatet benämns lärarna som L1-L8.

Meningstolkningen görs i diskussionen och syftar till att med utgångspunkt i angivna teoretiska perspektiv gå bakom det direkt sagda för att istället få syn på relationer och strukturer som inte syns vid första anblicken.

\section{Vilka lärare i fritidshem är}

Lärarna ger uttryck för olika gemensamma föreställningar och innebörder. När de identifierar sig som lagspelare är det ett uttryck för att de uppskattar att vara en del av ett arbetslag eftersom där samtalas om arbetet. Arbetet förändras regelbundet genom att elever, arbetslag och även innehåll i undervisningen byts ut, vilket bidrar till att lärarna beskriver sig som föränderliga. Att vara flexibel är ett annat adjektiv som lärarna använder om den egna lärargruppen och som hör samman med arbetets föränderlighet. Flexibiliteten beskrivs både på gott och på ont. En lärare säger att:

Det är ju lite därför som jag valt att bli fritidspedagog för jag gillar ju lite flexibiliteten och som du säger 'Det här året kan det bli så, nästa år kan det bli så’ [---]. Att det händer lite grejer. (L1)

En annan lärare resonerar kring flexibiliteten i förhållande till att bli använd som timvikarie:

Den här flexibiliteten som vi pratar om, alltså då värderar vi ju inte själva det vi gör om vi inte säger ifrån eller i alla fall är tydliga 'Ja, visst, jag kan det, det är kul att ha idrott!' säger man då fast egentligen så tycker man ju att det man själv hade planerat och skulle gjort är ju faktiskt viktigt. (L3)

Kluvenheten kring den egna flexibiliteten beror på att i vissa fall är den en inre drivkraft, medan i andra en pålaga från rektor. Flexibilitet som drivkraft beskrivs som att lärarna har en plan för arbetet, men att inom den råder flexibilitet. En lärare säger att de är:

[---] så otroligt proffsiga, på något sätt, så vi anpassar ju det, alltså vi anpassar ju våran verksamhet, vi anpassar våra lokaler, alltså vi gör ju det, vi löser ju det. Vi är skitduktiga! (L7)

När det gäller flexibilitet som pålaga rör det främst samverkan med den obligatoriska skolan. Lärarna berättar att de ofta rycks från sin planerade undervisning för att ersätta frånvarande lärare i den obligatoriska skolan. Det upplevs frustrerande, men lärarna säger sig inte ha något val när rektor anser att det ska prioriteras. Lärarna påpekar att i den bemärkelsen innebär flexibiliteten att nedvärdera den egna undervisningen. En av lärarna berättar att: 
Om vår idrottslärare är sjuk så kan det ju hända att man frågar mig om jag kan ta det vicket och då säger jag 'Ja, fast det är ju inte så att jag går här och har inget att göra utan jag har ju något annat. Om du bedömer att jag ska göra den prioriteringen då gör jag det.' [---] Det är så här, det där rutinmässigt 'Ja, vi tar någon från fritids.' Och då kan man känna, det kanske inte är så viktigt det vi gör. (L3)

Ett par lärare berättar också att paradoxalt nog har kraven på lärares behörighet försvårat samverkan eftersom det finns lärarkollegor som inte ser lärarna $\mathrm{i}$ fritidshem som behöriga att undervisa eleverna.

Lärarna är angelägna om att vara flexibla och lösa uppkomna situationer, men menar att det tenderar att bli en ond cirkel där de som lärargrupp får bekosta priset. Samtidigt tvingar stora elevgrupper lärarna att organisera verksamheten i fritidshemmet på ett sätt som gör att de beskriver sig som fyrkantiga. Fyrkantigheten innebär en hårdare styrning av eleverna och innehållet i fritidshemsverksamheten, något som lärarna uppfattar som tråkigt men nödvändigt. Lärargruppen beskriver sig också mot bakgrund av alla de elever, platser, tider och scheman som de måste ha kontroll över som att de blivit logistiker. Lärarnas tal om sin identitet är till stora delar samstämmig, samtidigt upplever de en otydlighet i fritidshemmets uppdrag. Eftersom det är viktigt för lärarna att både vara och att uppfattas som professionella, kompenserar de den upplevda otydligheten med, som någon uttrycker det, att vara" tydlig och stark" (L3). Att vara professionell blir för lärarna att visa utåt att de kan sin sak.

\section{Vad lärare i fritidshem gör och inte gör}

När lärarna talar om vad de gör, framstår deras organisering av och kontroll över eleverna som helt central. Beskrivningarna är mångfacetterade, men bottnar i ordet trygghet. De innebörder som lärarna lägger i trygghet redovisas nedan med stöd i de kategorier som framgår av metodavsnittet. Tydliga i ledarskapet innebär att vara väl inarbetade med varandra och bemöta elever på liknande sätt. Relationsskapa beskriver lärarna som att vara en närvarande vuxen som finns till hands. Att lära känna eleverna och att eleverna lär känna de vuxna och varandra uppfattas som centralt för tryggheten. Lärarna poängterar vikten av att även ha en god kontakt med föräldrarna, att de är trygga med att lärarna kan hantera elevgruppen och vet var eleverna befinner sig. Lärarna upplever det bekymmersamt att media uppmärksammar negativa nyheter om fritidshem. De anstränger sig därför för att visa föräldrarna att på just deras fritidshem fungerar det bra. Samtidigt får de stora förändringar som skett på senare år lärarna att fundera på att lämna yrket. En lärare sätter ord på sina tvivel:

Man försöker se de ljusa bitarna de finns ju fortfarande kvar även om arbetet har ändrats otroligt mycket de senaste åren. [---] De positiva bitarna kvar, det är att man jobbar med barn och det är väl det som göra att man älskar jobbet fortfarande, fast vissa dagar så vill man inte vara kvar, man vill gå hem och byta jobb [---]. (L6) 
Att lära känna eleverna har också ett annat syfte; genom att känna eleverna, deras intressen, var de brukar vara och vilka de helst leker med på fritidshemmet underlättas lärarnas möjlighet att kontrollera vad eleverna gör och befinner sig. Sättet att organisera den stora gruppen elever samt fritidshemsverksamheten $i$ sig är en del i det trygghetsskapande arbetet. De försöker uppnå tryggheten genom att dela in elevgruppen i mindre grupper. Lärarna menar att det också är viktigt för tryggheten att de är delaktiga i den obligatoriska skolan. Ett annat sätt att organisera för trygghet är att göra aktiviteter obligatoriska. Det förekommer att lärarna bestämmer vilka elever som ska leka tillsammans, var eller vad de ska leka. Motivet som anges är att eleverna ska lära känna fler i gruppen. Det är samtidigt ett sätt att få igång eleverna i aktiviteter och därmed undvika att elever drar omkring planlöst i lokalerna, stör och kommer i konflikt med varandra. Lärarna har tagit bort val i rutinsituationer genom att eleverna har fasta sittplatser i matsalen. Det syftar till att skapa en lugn atmosfär. Paradoxalt nog vittnar lärarna om att de inte alltid vet var eleverna är. Ibland när en förälder kommer för att hämta sitt barn vet läraren inte var eleven är eller om läraren sett eleven den dagen. Lärarna beskriver den obehagliga känsla som de får när de hamnar i en sådan situation, men vittnar om att de håller god min för att ge föräldrarna intrycket av att allt är under kontroll. En lärare säger att:

Jag känner att det är skönt att veta när föräldrarna kommer att man har koll på var barnen är någonstans. För det känns så hemskt när någon förälder kommer och ska hämta sitt barn: 'Ja, han är här.' [- - - ] Då vet man att han är där inne så går man in 'nähä, det var han inte nähä' [- - - . (L8)

En annan lärare berättar att det händer när en förälder kommer för att hämta sitt barn att hon inte vet om hon sett eleven den dagen:

Får man verkligen tänka efter, 'jo, men han var här' och den [känslan] känns ju inte skön. Även om jag vet att vi är ett arbetslag och har kontrollerat på lista och så, vi har ju koll på barnen, så känns det ju inte gott att inte veta. (L4)

Det förekommer att lärarna efter arbetsdagens slut kan komma på att de inte pratat med en viss elev på hela dagen:

Man vill ju göra ett så bra jobb och hinna med barnen och att de ska trivas, ja allihopa [---]. När man känner 'oj, idag har jag inte hunnit prata med det barnet.'

Då känns det inte bra. (L2)

Sammanfattningsvis framstår att skapa trygghet som grunden i det lärare i fritidshem gör.

\section{Ledarskap i grånslandet fritidshem}

Lärarna beskriver rektorernas ledarskap och vilka konsekvenser det får för dem, deras undervisning och relation till andra lärargrupper. De menar att rektorer förhåller sig 
på olika sätt till olika lärargrupper. När lärare i den obligatoriska skolan ska gå på fortbildning kan rektor tydligt informera kollegiet om det, medan hon ursäktar sig när motsvarande information ska ges om lärare i fritidshem. Ett annat exempel är när rektor inför kollegiet berömmer lärarna i fritidshem för deras rastverksamhet med motiveringen att de är utomhus i alla väder, istället för att föra fram den pedagogiska betydelse rastverksamheten har. En lärare berättar:

[---] det är ju det att hon inte sagt det på något möte att 'Nu har vi rastverksamhet och från och med den här terminen ska det vara varje rast och se vilka mål som är uppsatta för det'. För det har vi ju, vi har ju målen, vi har utvärderingar sen fem år tillbaka [...] hon stod bakom det. Inte att 'Nä, men vad NN är duktig och XX du är ute så mycket fast det regnar'. Det är ju inte det! Utan det är ju liksom ... Ja nu är jag upprörd! (L4)

Enligt läraren visar rektorn visserligen uppskattning för rastverksamheten, men ger den inte den dignitet som den förtjänar. Ett annat exempel handlar om hur en rektor talat om lärarna i fritidshem inför kollegiet efter att de fört fram kritik över att de blivit exkluderade från en utvärderingsdag:

Nej, nu klagar dom på fritids, nu känner inte dom att dom fick någon utvärderingsdag när dom fick jobba när vi hade stängt så vi får väl se om vi kan ordna det. Kan ni prata med era egna pedagoger så kanske [---] så löser ni det'. (L4)

Rektor lägger här över ansvaret för att arbetet som görs i samverkan ska kunna utvärderas på lärarna i den obligatoriska skolan. Det blir upp till de enskilda lärarnas goda vilja om det blir någon utvärderingsdag för lärarna i fritidshem.

Lärarna poängterar vikten av att rektor inför lärarkollegiet visar att hen är väl insatt $i$ fritidshemsverksamheten eftersom det ger både lärarna och fritidshemmet en högre status. Paradoxalt nog är det ofta lärarna själva som lär upp rektorerna om fritidshemmet. Lärarna uttrycker en trötthet över att det vare sig leder till bekräftelse av dem själva eller utveckling av fritidshemmet. En lärare berättar att de lärt upp en handfull rektorer. En annan berättar att de nyligen fått en ny och mer okunnig rektor än den förra, vilket lett till att fritidshemmet förlorat den status det tidigare haft. Lärarna menar att okunskapen lyser igenom hos rektorer eftersom de har svårt att ställa relevanta verksamhetsfrågor och en lärare (L3) menar att rektor "frågar mer för syns skull” än av genuint intresse. Lärarna beskriver hur de lär upp rektorer om fritidshem och lärarnas kompetens där och hur de servar rektorer med information och erforderliga dokument inför till exempel besök av Skolinspektionen. Den återkoppling som lärarna hoppas på uteblir dock. Lärarna poängterar vikten av att rektor kontinuerligt besöker fritidshemmets vardagsarbete, diskuterar aktuella verksamhetsfrågor samt sätter mål för verksamheten. Lärarna menar att rektor förlitar sig på att de reder upp saker själva. En lärare uttrycker problematiken på följande sätt:

[---] vi som brinner för fritidsverksamheten gör ju en bra fritidsverksamhet ändå att man inte har en bra ledning. Man liksom skiter i dom [ledningen] [---]. (L5) 


\section{Organisering av och innehåll i samverkan}

Lärarna upplever att de har för litet inflytande över samverkan med lärarna i den obligatoriska skolan. De vill arbeta tematiskt i arbetslag, men menar att lärare i den obligatoriska skolan tycker att det innebär svårigheter att ha kontroll över att eleverna uppnår specifika mål. Lärare i den obligatoriska skolan försöker ibland påverka innehållet även i fritidshemmet. En lärare berättar att en lärare i den obligatoriska skolan fört fram att när elever använder iPad i fritidshemmet bör de arbeta med program som stimulerar skrivandet. En annan skillnad som förs fram är att lärargrupperna har olika syn på utvecklingssamtal. Lärarna i fritidshem ser vinster för både elever och föräldrar med samverkan kring utvecklingssamtalen eftersom det ger en mer hel bild av barnens skolgång. Lärarna i fritidshem efterfrågar riktlinjer för utvecklingssamtal, så länge sådana saknas är det upp till den enskilde läraren i den obligatoriska skolan att avgöra om den vill samverka eller ej.

\section{Lärarnas institutionella identitet}

Lärarna ger uttryck för föreställningar som är gemensamma för hur de definierar sig som lärargrupp och det som är grunden för deras institutionella identitet. Lärarna är stolta över till exempel sin flexibilitet och använder den för att tillmötesgå och bli accepterade som kompetenta lärarkollegor. Lärargruppens gemensamma föreställningar används som referensramar i förhandlandet och positionerandet av fritidshemsverksamheten i relation till lärare i den obligatoriska skolan (Shibutani, 1955). Det går att beskriva de båda gränsländerna som två olika sociala världar alternativt som mikropolitiska arenor (Siskin, 1994). Det finns skillnader i föreställningar kring skolan, eleverna och arbetet mellan lärarna i fritidshemmet respektive den obligatoriska skolan. Dessa skillnader kan kopplas till mikropolitik och enskilda lärargruppers intressen, exempelvis att lärare i den obligatoriska skolan kan välja att avstå från att samverka med lärare i fritidshem eller från att täcka upp för lärare i fritidshem vid deras frånvaro. Lärarna i fritidshem är oftast inte den grupp som har tolkningsföreträde utan får anpassa sig. Närvänen och Elvstrand (2014) konstaterar även de att det finns en maktobalans mellan de båda lärargrupperna som bidragit till att lärare i fritidshems yrkesroll blivit mer diffus. Det finns en paradox i att just flexibiliteten, vilken lärarna sätter som en av sin institutionella identitets främsta kännetecken, utnyttjas på ett sätt under den obligatoriska delen av dagen så att lärarna knappt känner igen sig själva. De förväntas med kort varsel lämna arbetsuppgifter som de planerat för att istället användas som timvikarier. Det som efterfrågas är inte deras kompetens utan en funktion för att lösa ett problem. Newman menar att i förhandlingsprocesser som ligger till grund för gränsdragningar mellan lärargrupper framgår status och maktpositioneringar (Newman, 2006). Lärarna har små möjligheter att förhandla sina arbetsuppgifter utan får foga sig i situationen. Fritidshemmets status och position i förhållande till den obligatoriska skolan blir här uppenbar. 
Sedan 1990-talet har processer pågått kring hur gränsdragningen mellan fritidshem och obligatorisk skola ska göras. Att fritidshemmet både bokstavligt och bildligt blivit en del av grundskolan har med nödvändighet påverkat gränsdragningen mellan dessa båda kulturer som undervisar samma elever. I förhandlingarna ligger att den obligatoriska skolan har en lång och omfattande tradition, att den är obligatorisk och i hög grad sysslar med mätbara kunskaper samt att den i de flesta fall funnits på samma plats långt innan fritidshemmet kom dit. Ett led i processen har varit försök att öppna upp gränserna och uppvärdera fritidshemmets innehåll, till exempel genom att skapa gemensamma styrdokument. Det i sig utgör dock ett exempel på skolkulturens dominans när fritidshemmets verksamhet benämns som utbildning, aktiviteterna där kallas undervisning och de barn som är inskrivna kallas elever.

Lärare i fritidshem är ofta missnöjda med hur gränsdragningarna är gjorda och de förstår att det, såsom som Newman (2006) beskriver, har betydelse för deras inflytande och legitimitet. Newman menar att gränsdragningarna är avgörande för vem eller vilka som kommer att inkluderas eller exkluderas. Lärarna i studien använder flexibiliteten som ett medel för att förvärva status i relation till lärarna i den obligatoriska skolan. De tänjer på och förhandlar om gränserna för den egna yrkesidentiteten. Lärarna upplever situationen som stressande och att den urholkar deras institutionella identitet. Den leder inte heller till någon ökad legitimitet, vilket får till följd att lärarna känner sig utnyttjade. Deras strävan och anpassning handlar om att de vill bli accepterade och inkluderade i utbildningslandskapet som en jämlik part. Persson (2008) uttrycker det som att "[f] ritidspedagogens förändrade roll och funktion, från fritidens lärande till hjälplärare, blir ett av de tydligaste uttrycken för de makt- och statusförhållanden som råder i utbildningssystemet” (s. 105).

\section{Konsekvenser av gränsdragningar i utbildningslandskapet}

Strukturella förhållanden som stora elevgrupper, låg personaltäthet, låg andel pedagogiskt utbildade och dåligt anpassade lokaler tvingar lärarna att göra avkall på den för dem så viktiga flexibiliteten och istället styra eleverna hårdare. Lärarna upplever en otillfredsställelse över att vara kontrollerande av både elever och innehåll. Kärnan i den institutionella identiteten, såsom lärarna beskriver den, är att skapa trygghet. Löfdahl, Saar och Hjalmarsson (2011) konstaterar att ha kontroll framstår som en central kompetens för lärare $\mathrm{i}$ fritidshem och att lärare själva beskriver det som att de har "dubbla kompetenser" (s. 49) - att ha kontroll och att driva en pedagogisk verksamhet. Det lärarna i föreliggande studie tillägger är att de återkommande förlorar kontrollen över eleverna och upplever det stressande att inte ha kontroll. Att lärare finner sig i situationen och spelar med kan bero på att de vill framstå som professionella. Situationen riskerar att ytterligare sudda ut lärarnas institutionella identitet.

De strukturella problem som omnämns ovan finns på nationell nivå, men flera av problemen finns på skolnivå och är knutna till rektors ledarskap. Lärarna menar att 
rektorer ofta brister i kunskap och att de förlitar sig på att lärarna själva upprätthåller och utvecklar verksamheten. Lärarnas uppfattningar stämmer väl överens med vad Skolinspektionen $(2010 ; 2018)$ konstaterar i sina kvalitetsgranskningar; att många rektorer brister i kunskap om fritidshemmets verksamhet och de styrdokument som reglerar fritidshem. Det har fått till följd att de i liten utsträckning engagerar sig i utvecklingen av fritidshemmets verksamhet och dess kvalitet. Lärarna i föreliggande studie uttrycker en uppgivenhet över att behöva lära upp rektorer. Att lärarna finner sig i situationen beror på att de värnar kvaliteten i fritidshemmet. De är också medvetna om att rektor har en avgörande betydelse för legitimeringen av deras kompetens och fritidshemmets verksamhet.

\section{Avslutande reflektion}

Sammantaget konstateras att lärarna har gemensamma föreställningar om vad som utgör deras institutionella identitet och den kan sammanfattas i att skapa trygghet för främst eleverna, men också för deras föräldrar. Det gör lärarna genom sitt sätt att vara och göra. Mot bakgrund av rådande strukturella förhållanden är kontroll centralt för att uppnå och bibehålla trygghet. Utifrån de gränsdragningsprocesser mellan lärare i fritidshem och lärare i obligatorisk skola som beskrivs kan vi konstatera att det finns en maktobalans. Lärare i fritidshem försöker få legitimitet genom att anpassa sig och visa sig kompetenta inför lärarkollegiet och rektor. Lärarna beskriver hur situationen löser upp deras institutionella identitet.

Lärarna vet vad de kan bidra med för elevers lärande och utveckling, både i fritidshem och i samverkan. Det finns en frustration över de hinder som gör att de inte kan använda sin kompetens. Vi menar att många av gränslandsproblemen skulle vara möjliga att arbeta med på den lokala skolan. I det arbetet är rektors ledarskap avgörande. Jarl, Blossing och Andersson (2016) visar att framgångsrika skolor karaktäriseras av sammanhang där skolledare och merparten av lärarna omfattar gemensamma regler, normer och föreställningar vilka gällt under lång tid. Det här saknas på mindre framgångsrika skolor vilka utmärks av föränderlighet och avsaknad av tydliga och delade mål samt långsiktiga strategier. Isaksson (2013) visar i sin studie på ett liknande resultat, men att de mer framgångsrika skolorna har ett utvecklat samarbete mellan skola och fritidshem där arbetslag organiseras så att fritidshemspersonal ansvarar för delar i skolarbetet och där använder sin kompetens. Utmärkande är ett gemensamt förhållningssätt till elevers kunskap och lärande. I de mindre framgångsrika skolorna brister framförallt samarbetet mellan skola och fritidshem.

Fritidshemmet som gränsland kommer i kläm i utbildningslandskapet. Det gör att fritidshemmet har svårt att leva upp till grundläggande mål om att ta utgångspunkt i elevers behov, nyfikenhet, intressen, erfarenheter och initiativ. Risken är att undervisningen inte blir den meningsfulla fritid som den syftar till och inte heller bidrar till måluppfyllelsen. Något som ytterligare förstärkt gränslandsproblematiken är den kunskapseffektiva skolans utbredning med fokus på mätbara ämneskunskaper och 
färdigheter, vilket medfört att fritidshemmets mer svårmätta innehåll kommit i skymundan. Saar, Löfdahl och Hjalmarsson (2012) anser att fritidshemmets verksamhet "hamnat i ett slags ideologiskt och pedagogiskt vakuum och dess funktion som pedagogisk institution blivit allt mindre tydlig" (s. 1).

Rektor har ansvar för att arbeta med gränslandsproblematiken och skapa ett gott samtalsklimat där samtal om lärargruppers olika roller, status och positioner upplevs som meningsfulla. Det förutsätter ömsesidighet. Dachler och Hosking (1995) framhåller att det är genom perspektivtagande i förhandlingsprocesser som ledare och medarbetare lär känna varandra. Det är en stor utmaning för rektorer att öppna gränser mellan verksamheter och lärargrupper för att nå ett hållbart samarbete som grundar sig på gemensamma regler, normer, föreställningar och mål för undervisningen och där olikhet bidrar till mångfald. Till syvende och sist handlar det om att skapa så goda förutsättningar som möjligt för elever att utveckla en mångfald av kunskaper.

\section{Författarbiografi}

Ann Ludvigsson är fil dr i pedagogik och arbetar som lektor i pedagogik vid Jönköping University, Sverige. Ludvigssons forskning är fokuserad på ledarskap i skolan och hur rektorer och lärare influerar varandra i det vardagliga arbetet. Under senare tid har forskningen också inriktat sig på frågor som handlar om fritidshem och kvalitet i vuxenutbildning.

Carin Falkner, fil dr i pedagogik, är anställd som lektor i pedagogik vid Jönköping University och har även en examen som fritidspedagog. Falkners forskning rör barns och ungas fritid $\mathrm{i}$ både organiserad och mer fri form. Senare år har forskningen handlat om fritidshemmets uppdrag och lärares profession. Sammanfattningsvis har forskningen fokus på meningsfull fritid och bildning.

\section{Referenser}

Ackesjö, H. \& Landefrö, A. (2014). På spaning efter en gräns. Några barns perspektiv på skillnader mellan förskoleklassens och fritidshemmets verksamheter i Sverige. Barn. 3 s. 27-43.

Ackesjö, H. \& Persson, S. (2010). Skolförberedelse i förskoleklass. Att vara lärare-i-relation i gränslandet. Pedagogisk Forskning $i$ Sverige 15 (2), s. 142-163.

Alvesson, M. (2007). Företagskultur och organisationsidentitet - stödjande normsystem eller hjärntvätt. I: M. Alvesson \& S. Svenningsson (red.), Organisationer, ledning och processer. Lund: Studentlitteratur.

Andersson, B. (2010). Introducing assessment into Swedish leisure-time centres - pedagogues' attitudes and practices. Education inquiry 1:3, s. 197-209.

Brunsson, N. \& Olsen, J. P. (1990). Makten att reformera. Stockholm: Karlssons bokförlag.

Calander, F. (1999). Från fritidens pedagog till hjälplärare: Fritidspedagogers och lärares yrkesrelation i integrerade arbetslag. Doktorsavhandling, Uppsala universitet, Uppsala.

Dachler, P. \& Hosking, D. M. (1995). The primacy of relations in socially constructing organizational realities. In D. M. Hosking, H. P. Dachler \& K. Gergen, J. (Red.), Management and Organization: Relational Alternatives to Individualism. Vermont: Ashgate Publishing Company.

Haglund, B. (2004). Traditioner $i$ möte. En kvalitativ studie av fritidspedagogers arbete med samlingar $i$ skolan. (Göteborg Studies in Educational Sciences, 224). Göteborg: Acta universitatis Gothoburgensis. 


\section{Ann Ludvigsson og Carin Falkner}

Hansen, M. (1999). Yrkeskulturer $i$ möte. Läraren, fritidspedagogen och samverkan. (Göteborg Studies in Educational Sciences, 131). Göteborg: Acta universitatis Gothoburgensis.

Hjalmarsson, M. (2013). Governance and Voluntariness for Children in Swedish Leisure- Time Centres: Leisue-Time Teachers Interpreting Their Task and Everyday Practices. International fournal for Research on Extended Education. 1(1), s. 86-95.

Hosking, D. \& Fineman, S. (1990). Organizing Processes. Fournal of Management Studies, 27 (6), s. $583-604$.

Isaksson, E. (2013). Fämför grundskolorprojektet. Stockholm: Utbildningsförvaltningen, Stockholms stad.

Jarl, M., Blossing, U. \& Andersson, K. (2016). Skolans organisation påverkar resultaten. I Vetenskapsrådets Resultatdialog 2016, s. 72-77.

Johansson, I. (2000). Innehållet $i$ den nya skolan: Erfarenheter från verksamheter som innehåller förskoleklass, skola och fritidshem. Stockholm: Socialtjänstförvaltningen, Forsknings- och utvecklingsenheten.

Johansson, R. (2002). Nyinstitutionalismen inom organisationsanalysen. Lund: Studentlitteratur.

Johansson, R. (2009). Vid den institutionella analysens gränser: Institutionell organisationsteori i Sverige. Nordiske Organisasjonsstudier. 11(3), s. 5-22.

Kvale, S. (1997). Den kvalitativa forskningsintervjun. Lund: Studentlitteratur.

Ludvigsson, A. (2009). Samproducerat ledarskap: Hur rektorer och lärare formar ledarskap $i$ skolans vardagsarbete. Doktorsavhandling, Högskolan för lärande och kommunikation, Jönköping.

Löfdahl, A., Saar, T. \& Hjalmarsson, M. (2011). Fritidshemmets potentiella didaktik och barns och pedagogers gemensamma kunskapsmöjligheter. I A. Klerfelt \& B. Haglund (Red.), Fritidspedagogik - fritidshemmets teorier och praktiker. Stockholm: Liber, s. 42-60.

Meyer, J. W. \& Rowan, B. (1977). Institutionalized organizations: Formal Structure as Myth and Ceremony. American Fournal of Sociology, 83, s. 340-346.

Morgan, D. L. (1997). Focus Groups as Qualitative Research. London: SAGE Publications.

Newman, D. (2006). The lines that continue to separate us: borders in our' borderless' world. Progress in Human Geography 30, (2), s. 143-161.

Närvänen, A-L. \& Elvstrand, H. (2014). På väg att [om]skapa fritidshemskulturer. Om visioner, gränsdragningar och identitetsarbete. Barn 3, s. 9-23.

Persson, S. (2008). Forskning om villkor för yngre barns lärande iförskola, förskoleklass och fritidshem. Vetenskapsrådets rapportserie. Stockholm: Vetenskapsrådet.

Powell, W. W. \& Colyvas J. A. (2008). Microfoundations of Institutional Theory. I R. Greenwood, C. Oliver, R. Suddaby \& K. Sahlin (Red.), The SAGE Handbook of Organisational Institutionalism. London: SAGE Publication. s. 276-298.

Saar, T., Löfdahl, A. \& Hjalmarsson, M. (2012). Kunskapsmöjligheter i svenska fritidshem. Nordisk barnehageforskning. 5:3, s. 1-13.

SFS 2010:800. Skollag. Stockholm: Utbildningsdepartementet.

Shibutani, T. (1955). Reference Groups as Perspectives. American fournal of Sociology, 60, s. 562-569.

Siskin, L. S. (1994). Realm of knowledge. Academic Departments in Secondary Schools. New York: Routledge Falmer.

Skolinspektionen (2010). Kvalitet ifritidshem. Kvalitetsgranskning Rapport 2010:3. Stockholm: Skolinspektionen.

Skolinspektionen (2018). Undervisning $i$ fritidshemmet inom områdena språk och kommunikation samt natur och samhälle. Kvalitetsgranskning Rapport 2016:207. Stockholm: Skolinspektionen.

Skolverket (2000). Finns fritids? En utvärdering av kvaliteten i fritidshem. Stockholm: Fritzes.

Skolverket (2005). Skolverkets lägesbedömning. Rapport 264.

Skolverket (2014). Skolverkets allmänna råd med kommentarer. Fritidshem. Stockholm: Skolverket.

Skolverket (2016). Läroplan för grundskolan, förskoleklassen och fritidshemmet 2011 (Reviderad 2017). Stockholm: Skolverket.

Skolverket (2017). PM, Dnr 2017:591.

SOU 1997:21. Växa i lärande. Förslag till ny läroplan för barn och ungdom 6-16 år. Stockholm: Statens offentliga utredningar.

Stecher, L., Maschke, S., Klieme, E., Fischer, N., Dyson, A., Mahoney, J., ... Hoon Bae, S. (2013). Editorial. International fournal for Research on Extended Education. 1 (1), s. 1-2.

Öksnes, M., Knutas, A., Ludvigsson, A., Falkner, C. \& Kjaer, B. (2014). Lekens rolle i skandinaviske skolefritidsordninger. Barn 3, s. 107-123. 